\title{
Choanephora rot caused by Choanephora cucurbitarum on Brassica chinensis in Thailand
}

\author{
Chaninun Pornsuriya $^{1}$ - Thanunchanok Chairin ${ }^{1} \cdot$ Narit Thaochan $^{1}$. \\ Anurag Sunpapao ${ }^{1}$
}

Received: 24 November 2016 / Accepted: 22 February 2017/Published online: 1 March 2017

(C) Australasian Plant Pathology Society Inc. 2017

\begin{abstract}
In July 2016, wet rot was observed on leaves of Brassica chinensis in a private greenhouse in Hatyai city, Songkhla province, Thailand. The fungal pathogen infected young and expanded leaves. The fungus was identified by morphological characterization and molecular analysis as Choanephora cucurbitarum. Pathogenicity test revealed that C. cucurbitarum could infect $B$. chinensis.
\end{abstract}

Keywords Molecular · Morphology · Pak-Choi · Pathogenicity

Brassica chinensis (Pak-Choi) is a type of Chinese cabbage in the family Brassicaceae, which do not form a head. The chinensis variety of Brassica is widely grown in southern China and Southeast Asia for use as vegetable in foods. It has smooth dark green leaves. A $100 \mathrm{~g}$ portion of fresh B. chinensis supplies $13 \mathrm{cal}$ and is rich in vitamins $\mathrm{A}, \mathrm{C}$ and $\mathrm{K}$ (Noia 2014). Several diseases have been reported as causing devastation in Brassica plantations. For instance, the clubroot disease caused by Plasmodiophora brassicae has been reported on B. chinensis in Korea (Kim et al. 2009). The soft rot disease caused by Dickeya dadantii subsp. dieffenbachiae has $38-56 \%$ incidence rate in $B$. chinensis in Malaysian commercial fields (Golkhandan et al. 2016).

The zygomycetes fungi are known to infect several economical plant products. The Choanephora, one of fungal

Anurag Sunpapao

anurag.su@psu.ac.th

1 Pest Management Biotechnology and Plant Physiology Laboratory, and Department of Pest Management, Faculty of Natural Resources, Prince of Songkla University, Hatyai 90110, Thailand genus of zygomycetes is known to cause devastating damage on withering floral part and fruits of many plant species (Agrios 2005). In Thailand, B. chinensis is cultivated widely in pots or with hydroponic systems, but little is known about its disease problems. In July 2016, wet rot was found in $B$. chinensis leaves in a private hydroponic greenhouse in Hatyai city, Songkhla, Thailand. Therefore, the aim of this research was to identify and characterize that wet rot disease on $B$. chinensis in Thailand. To identify the causal agent, morphological examination, as well as molecular analysis and pathogenicity tests were conducted.

The fungi initially infected young and expanded leaves (Fig. 1 a-c). The infected leaves became water-soaked and were covered with a dark mass of sporangiophores (Fig. $1 \mathrm{a}-\mathrm{d}$ ). The fungal pathogen was isolated to a pure culture on water agar and potato dextrose agar (PDA). The fungus grew rapidly on PDA to cover the whole Petri dish ( $9 \mathrm{~cm}$ in diam.) within $48 \mathrm{~h}$. After 7 days on PDA at $25^{\circ} \mathrm{C}$ and under a $12 \mathrm{~h} / 12 \mathrm{~h}$ dark/light regime the isolate produced white colonies that later turned yellow or pale brown with abundant sporangiola. Fungal structures from fresh leaf samples were mounted with water on a glass slide and observed under a light microscope (Leica DM750, Leica Microsystems, Germany). Sporangiophores were 5-13 $\mu \mathrm{m}$ in width and 1$10 \mathrm{~mm}$ in length, erect, solitary, unbranched, non-septate, with clavate vesicles formed at their apices. Monosporous sporangiola were brown to dark brown, ellipsoid to ovoid, 8-15 $\mu \mathrm{m}$ in width and 9-22 $\mu \mathrm{m}$ in length (Fig. 1 e). Zygosporangia were not observed. These morphometric traits were consistent with Choanephora cucurbitarum (Kirk 1984). Fungal specimens were deposited in the Culture Collection of Pest Management Department, Faculty of Natural Resources, Prince of Songkla University, Thailand under the accession number PSU-PMPC01.

Fungal pathogens cultured on PDA for 7 days were harvested for DNA extraction. Genomic DNA was extracted from 
Fig. 1 Choanephora rot on Brassica chinensis caused by Choanephora cucurbitarum. Symptoms on young leaves (a \& b) and on expanded leaf (c), sporangiophores bearing sporangiola $(\mathbf{d})$, and monosporous sporangiola (e) Scale bars $\mathrm{d}=0.5 \mathrm{~mm}, \mathrm{e}=20 \mu \mathrm{m}$
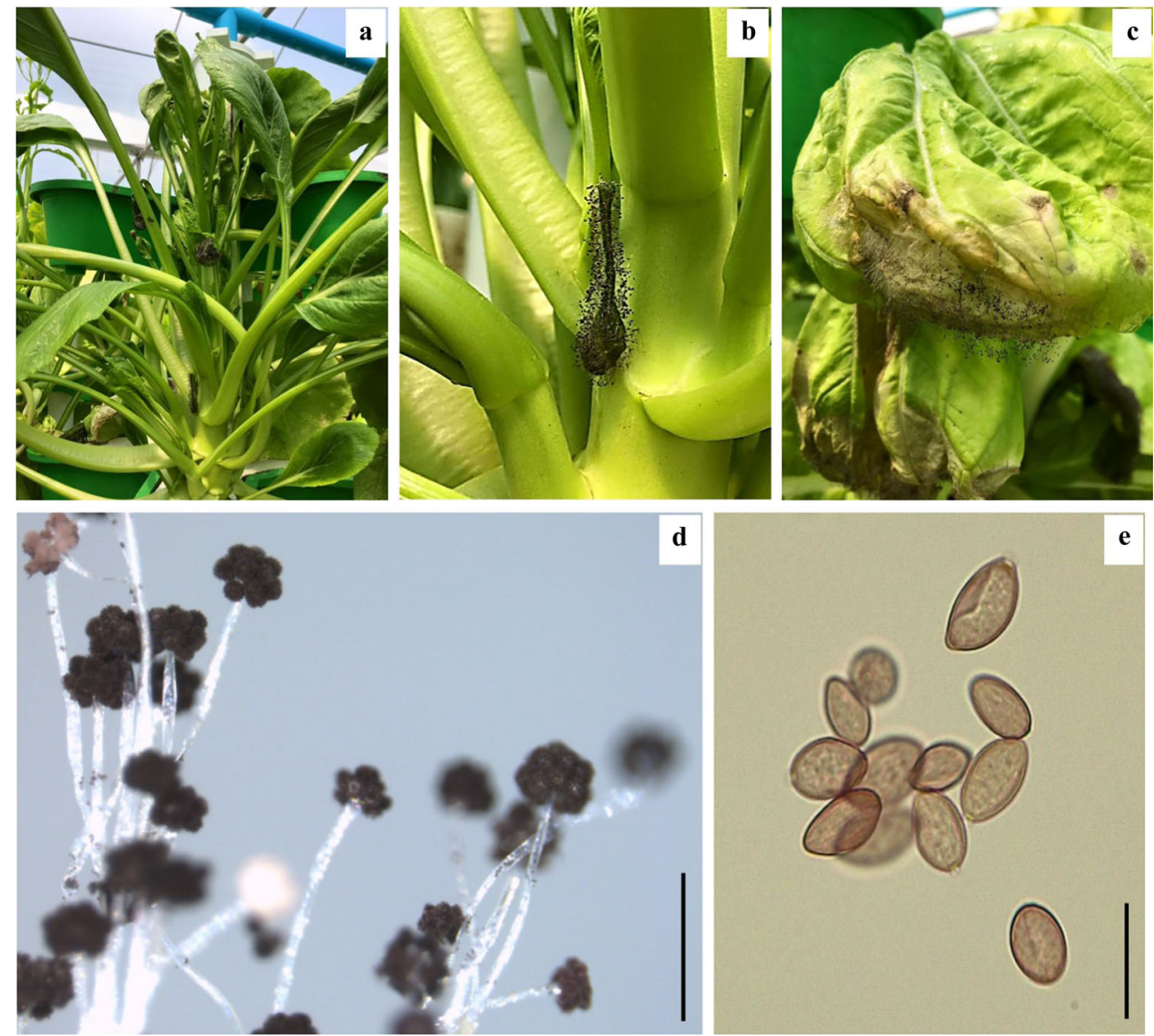

mycelia using the CTAB method (Doyle and Doyle 1987; Doyle and Dickson 1987; Cullings 1992). Inter transcribed spacer (ITS) region of ribosomal DNA (rDNA) was amplified by using ITS1 and ITS4 primer pair (White et al. 1990). The ITS gene regions were amplified using BIO-RAD T100 ${ }^{\mathrm{TM}}$ Thermal Cycler (BioRad, Hercules, CA, USA). The PCR was carried out sequentially in a volume $50 \mu$ containing $2 \times$ Dreamtaq Green PCR Master Mix (Thermo Scientific), $10 \mathrm{pmol}$ of each primer and $50 \mathrm{ng}$ of DNA template. The cycling parameters were $3 \mathrm{~min}$ at $95{ }^{\circ} \mathrm{C}, 35$ cycles $30 \mathrm{~s}$ at $95^{\circ} \mathrm{C}, 30 \mathrm{~s}$ at $50^{\circ} \mathrm{C}$, an extension for $1 \mathrm{~min}$ at $72^{\circ} \mathrm{C}$ with final extension of $10 \mathrm{~min}$ at $72{ }^{\circ} \mathrm{C}$.

Sequencing was performed by Macrogen Sequencing Service (Macrogen, Seoul, Korea) with the same primers used for PCR amplification. The sequence of ITS was blasted in the database of NCBI (National Center for Biotechnology Information). Nucleotide sequences were aligned with MEGA version 6.0 (Tamura et al. 2013). Phylogenetic analysis was performed using the maximum likelihood with 1000 bootstrap replications.

PCR amplification of the ITS gene region gave fragments about 569 base pairs (bp) and the sequence was deposited in GenBank under the accession number LC189371. BLAST search indicated that the ITS sequence was $99 \%$ similar to C. cucurbitarum available in GenBank (accession number
KU316934, KX790359). A phylogenetic analysis showed the isolated sample was conspecific with other members of C. cucurbitarum (Fig. 2). The isolate LC189371 and C. cucurbitarum (KX790359, KY080447, KU316934) were clustered together with $96 \%$ bootstrap support (Fig. 2).

The pathogenicity tests were carried out in young healthy B. chinensis plants (30-day-old). The isolated fungal pathogens were cultured on PDA for 14 days at room temperature $\left(28 \pm 2{ }^{\circ} \mathrm{C}\right)$ and a spore suspension was prepared with sterile

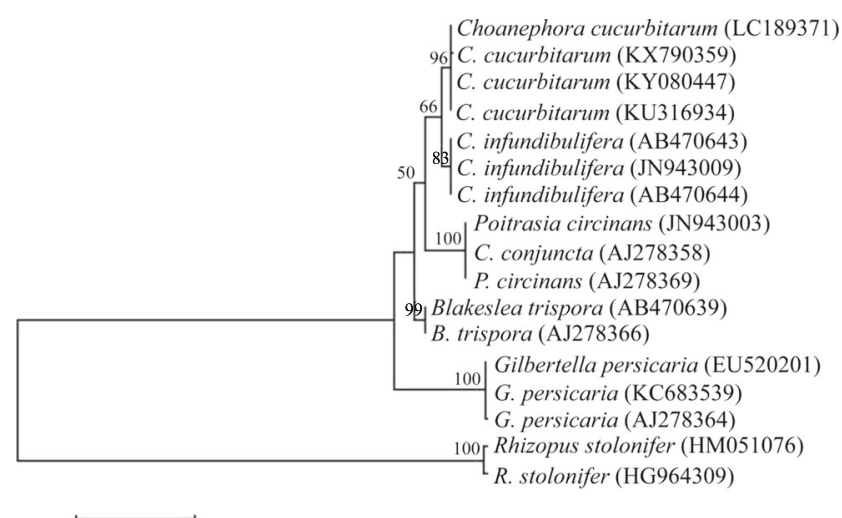

Fig. 2 Phylogenetic tree of Choanephora cucurbitarum including related species from GenBank, based on rDNA ITS gene sequences. Rhizopus stolonifer is used as an outgroup 
distilled water $\left(1 \times 10^{6}\right.$ spores $\left./ \mathrm{mL}\right)$. Ten healthy plants were sprayed with the spore suspension, while plants sprayed with water alone served as the negative control. The inoculated plants were covered with plastic bags for $48 \mathrm{~h}$ and kept in a greenhouse $\left(30{ }^{\circ} \mathrm{C}\right.$ and $75-90 \%$ relative humidity). Water-soaked lesions emerged on the leaves 3 days after inoculation, and these then rotted within 7 days. All the inoculated leaves of $B$. chinensis plants showed the typical disease symptoms within 10 days, whereas the control remained healthy. Choanephora cucurbitarum was re-isolated from the inoculation induced lesions and was morphologically identical to the original isolates. No symptoms developed on the stems or on other parts of $B$. chinensis plants, with the exception of leaves. These results confirmed that $C$. cucurbitarum could infect $B$. chinensis and cause the wet rot disease on its leaves.

It has been documented that $C$. cucurbitarum causes wet rot on cabbage plug seedlings in Japan (Kubota and Abiko 2001). This pathogen has been also found to cause the soft rot on eggplants in Korea (Kwon and Jee 2005). Furthermore, Choanephora flower rot on Abelmoschus manihot caused by C. cucurbitarum has also been recently reported in Korea (Park et al. 2015). However, there is no prior report of $C$. cucurbitarum causing wet rot disease on $B$. chinensis. This is the first report of Choanephora rot of $B$. chinensis being caused by $C$. cucurbitarum, in Thailand or elsewhere. There is an increasing trend in Choanephora rot disease prevalence in several parts of Asia, probably associated with the long period of high rainfall, high humidity, and tropical temperatures (Kwon and Jee 2005). An epidemic of Choanephora rot in Asia could cause devastating damage to the plantation crops, and the farmers need to find appropriate ways to manage this disease in the near future.
Acknowledgements The authors would like to thank the Prince of Songkla University for funding and facilities. The copy-editing service of RDO/PSU and the helpful comments of Dr. Seppo Karrila are gratefully acknowledged.

\section{References}

Agrios GN (2005) Plant pathology, 5th edn. Academic Press, San Diego Cullings KW (1992) Design and testing of a plant-specific PCR primer for ecological and evolutionary studies. Mol Ecol 1:233-240

Doyle JJ, Dickson EE (1987) Preservation of plant samples for DNA restriction endonuclease analysis. Taxon 36:715-722

Doyle JJ, Doyle JL (1987) A rapid DNA isolation procedure for small quantities of fresh leaf tissue. Phys Bull 19:11-15

Golkhandan E, Kamaruzaman S, Zainalabidin MA, Nasehi A (2016) First report of soft rot disease on Pak Choi (Brassica chinensis) caused by Dickeya dadantii sbsp. dieffenbachiae in Malaysia. Plant Dis 100(1):209

Kim WG, Moon MH, Kim JH, Choi HW, Hong SK (2009) Occurrence of clubroot on Pak-Choi caused by Plasmodiophora brassicae. Mycobiology 37(1):67-71

Kirk PM (1984) A monograph of the Choanephoraceae Commonwealth Mycological Institute. Mycol Pap 152:16-25

Kubota M, Abiko K (2001) A new disease of cabbage plug seedlings caused by Choanephora cucurbitarum (Berk. Et Rav.) Thaxter. Proc Kansai Plant Prot Soc 43:9-10

Kwon J-H, Jee H-J (2005) Soft rot of eggplant (Solanum melongena) caused by Choanephora cucurbitarum in Korea. Mycobiology 33(3):163-165

Noia JD (2014) Defining powerhouse fruits and vegetables: a nutrient density approach. Center for Disease Control and Prevention 11:1-5

Park J-H, Cho S-E, Hong S-H, Shin H-D (2015) Choanephora flower rot caused by Choanephora cucurbitarum on Abelmoschus manihot. Trop Plant Pathol 40:147-149

Tamura K, Stecher G, Peterson D, Filipski A, Kumar S (2013) MEGA6: molecular evolutionary genetics analysis version 6.0. Mol Biol Evol 30:2725-2729

White TJ, Bruns T, Lee S, Taylor J (1990) Amplification and direct sequencing of fungal ribosomal RNA genes for phylogenetic. In: Innis MA, Gelfand DH, Sninsky JJ, White TJ (eds) PCR protocols: a guide to methods and applications. Academic, San Diego, pp 315-322 